\title{
BANGGAI CARDINALFISH (Pterapogon kauderni) AND THE ATTEMPT FOR THE INCLUSION OF CITES APPENDIX II
}

\section{IKAN CAPUNGAN BANGGAI (Pterapogon kauderni) DAN UPAYA UNTUK MENDAFTARKAN SPESIES INI DALAM APPENDIX II CITES}

\author{
Tonny R. Soehartono ${ }^{1}$ \& Ani Mardiastuti ${ }^{2 *}$ \\ ${ }^{1}$ Senior Fellow, Nata Samastha Foundation, Bogor, 16810, Indonesia \\ ${ }^{2}$ Department of Forest Resources Conservation and Ecotourism, \\ Faculty of Forestry and Environment, IPB University, Bogor, 16680, Indonesia \\ *E-mail: aniipb@indo.net.id, ani_mardiastuti@apps.ipb.ac.id
}

\begin{abstract}
Banggai cardinalfish (Pterapogon kauderni) is a commercial ornamental fish originated and endemic to Banggai Islands of Indonesia. The objective of this paper was (a) to examine the sequence and the reasons to include Banggai cardinalfish into CITES Appendix II by USA and again by European Union, (b) to explain the responds (policy and actions) by Indonesian Government, and (c) to analyse the impact of the international and national policies related to CITES decisions. Basically, USA and EU claimed that the exploitation of Banggai cardinalfish for export was over-harvested and unsustainable, and thus they proposed to include the species into CITES Appendix II. The Government of Indonesia considered that the species has been appropriately managed in accordance to sustainable yield, and thus this species no need to include in the CITES Appendix II. To ensure its sustainability, the Government has issued a number of activities and interventions, among other, imposing limited access to harvest area, establishment of breeding operations, study of its natural population as well as development of a national action plan. After a long process involving various institutions, Bangai cardinalfish was decided not to be included in CITES Appendix II. Conservation measures, however, need to be continued by Indonesian Government to make sure that the population and the trade of Banggai cardinalfish will be sustainable in the future.
\end{abstract}

Keywords: endemic, Indonesia, international trade, ornamental fish, Sulawesi, sustainable

\begin{abstract}
ABSTRAK
Ikan capungan Banggai (Pterapogon kauderni) adalah salah satu spesies ikan hias endemik dari Kepulauan Banggai. Tujuan makalah ini adalah (a) memberikan informasi tentang urutan kejadian dan alasan mengapa ikan capungan Banggai ingin dimasukkan dalam Apendiks II CITES oleh Amerika Serikat dan oleh Uni Eropa, (b) menjelaskan tentang tindakan (kebijakan dan kegiatan) yang dilakukan oleh Pemerintah Indonesia, dan (c) menganalisis dampak keputusan dan kebijakan internasional terkait keputusan CITES. Pada prinsipnya, Amerika Serikat dan Uni Eropa menganggap bahwa pemanenan ikan capungan Banggai untuk kepentingan ekspor dilakukan secara berlebihan dan tidak lestari, sehingga kedua negara (kelompok negara) tersebut mengusulkan untuk memasukkan ikan capungan Banggai dalam Apendiks II CITES. Pemerintah Indonesia meyakini bahwa ikan capungan Banggai telah dikelola dengan baik sesuai dengan prinsip kelestarian, sehingga ikan ini tidak perlu dimasukkan ke CITES Appendiks II. Untuk memastikan kelestarian ikan ini, Pemerintah telah melakukan berbagai kebijakan dan tindakan, termasuk membatasi daerah yang diperbolehkan untuk dipanen, mengembangkan upaya budidaya, melakukan penelitian tentang estimasi populasi di alam, serta merumuskan rencana aksi nasional. Setelah melalui proses panjang yang melibatkan berbagai institusi, ikan capungan Banggai diputuskan untuk tidak dimasukkan dalam Apendiks II CITES. Namun demikian, upaya konservasi tetap perlu dilanjutkan oleh Pemerintah Indonesia untuk memastikan bahwa populasi dan perdagangan ikan capungan Banggai ini akan tetap lestari pada masa mendatang.
\end{abstract}

Kata kunci: endemik, ikan hias, Indonesia, pemanfaatan lestari, perdagangan internasional, Sulawesi 


\section{INTRODUCTION}

Banggai cardinalfish (Pterapogon kauderni), or 'ikan capungan Banggaian Banggai' in the Indonesian language, was first discovered by Swedish zoologist Walter Kaudern in 1920 and later re-discovered in 1994 by Roger Steene and Gerald R. Allen (Talbot et al., 2012; Indrawan \& Suseno, 2008). The fish is endemic to Indonesia and its natural distribution is restricted to 27 small islands of the Banggai Archilepago at the far eastern-end of Central Sulawesi, Indonesia (Vagelli \& Erdmann, 2002; Vagelli, 2005). New small sub-populations that have escaped or intentionally introduced can be found in Lembeh Straits (North Sulawesi, Indonesia) (Erdmann \& Vagelli 2001; Makatipu et al., 2013) and Ambon (Maluku, Indonesia) (FAO, 2016).

The species lives in shallow microhabitat, commonly occurs in seagrass beds, mangrove, and reef habitat, usually with the depth between 1.5-2.5 m, although it can also be found up to $4.5 \mathrm{~m}$ (Vagelli, 2004). Banggai cardinalfish frequently is associated with long-spine sea urchins, Diadema setosum (32\%), sea anemone (54.1\%) and branching corals (44\%) (Vagelli \& Erdmann, 2002).

This beautiful and uniquely-shaped fish entered into the commercial global market in 1995 and the international demand of the species for the aquarium industry has been increasing ever since. Export records from Indonesia for 1995 to 2004 was estimated between 600,000 to 900,000 specimens annually (CITES, 2007). The trade figure obviously raising concern on the pressure on the wild populations in their limited natural range. Knowing that this fish has been heavily traded in the international market, while conservation measures (protection status, captive breeding, harvest management) were not in placed yet, in 2007 USA proposed this species into CITES Appendix II. Prior to USA's proposal, Banggai cardinalfish was already listed as
Endangered (EN) under IUCN Red List Category starting 1 March 2007 (IUCN, 2007).

CITES is a Convention that control trade in international level. When a species is listed in the Appendix II, the number of specimens being traded in the international market has to be controlled accordingly to ensure sustainable harvest, usually through a quota system. As for Appendix I, it basically listed species that prohibit to be exported (with few exception). Any Party (member) of the Convention may proposed to include a particular species into CITES Appendix, even though the Party does not 'have' the species. Decisions of CITES were taken during Conference of Parties (COP), which held every three years. Under CITES governance, there is an Animals Committee, the committee which provide technical and scientific advice related to fauna in international trade.

Export of the species that already listed in Appendix II to other countries need to be accompanied by some legal papers from the Indonesia's Management Authority in Jakarta, and thus may create some hassles for local people. The CITES Management Authority for Indonesia is the Ministry of Environment and Forestry (or the Ministry of Forestry, when the issue of the Banggai cardinalfish emerged in the international community). Matters related to the scientific issues are taken by Scientific Authority. The CITES Scientific Authority for Indonesia is the Indonesian Institute of Science (Lembaga Ilmu Pengetahuan Indonesia, LIPI) (Soehartono \& Mardiastuti, 2002).

Aware that Banggai cardinalfish has a high commercial value, especially for the local fishermen, Indonesia maintained the species as not protected under Indonesian Law (KKP, 2018), and thus harvest from the wild is allowed. In relation to harvest for export, disputes over whether this species should or should not be included in the CITES Appendix II still continue. The objective of this paper was (a) to examine 
the sequence and the reasons to include Banggai cardinalfish into CITES Appendix II by the USA and European Union, (b) to explain the responds (policy and actions) taken by the Indonesian Government, and (c) to analyse the impact of the international and national policies related to CITES decisions.

\section{RESEARCH METHODS}

Desk studies were conducted to collect information related to Banggai cardinalfish, as well as scientific papers and documents linked to the attempt to include this species into CITES Appendix. Series of interview were conducted to persons who has good knowledge related to CITES and the Banggai cardinalfish, including policy maker (i.e. Ministry of Marine Affairs and Fisheries), Indonesia's CITES Management Authority (i.e. Directorate of Biodiversity Conservation - Ministry of Forestry), Indonesia's CITES Scientific Authority (i.e. Indonesian Institute of Science), and practitioner (i.e. Yayasan Alam Indonesia Lestari and Yayasan Palu Hijau).

Analysis was based on the cumulative results of desk study. Knowledge gained from personal involvement of both Authors during CITES Conference of Parties (COP) 14 in The Hague (Netherlands) was also added in the analysis. Impact of the policy was analyzed based on ecological knowledge of both Authors.

\section{RESULTS AND DISCUSSION}

\subsection{Results}

3.1.1. The First Attempt for the Inclusion of the Banggai Cardinalfish (Pterapogon kauderni) into CITES Appendix II

At the CITES COP 14 in June 2007, in consultation with the CITES Scientific Authority and Management Authority of Indonesia, USA submitted a proposal for amending the Banggai cardinalfish into CITES Appendix II (CITES 2007). The main reason for the amending the species was because there was a highly indication that the harvest from the wild was not sustainable in their small geographic range. The proposal was backed up by scientific bases and field analysis prepared by Dr. Alejandro A. Vagelli, who had conducted extensive studies on the Banggai cardinalfish in its natural habitat since 2001 (i.e., Vagelli \& Erdmann, 2002; Vagelli, 2004; Vagelli, 2005), in association with Yayasan Pemerhati Lingkungan, a local NGO in the District of Banggai.

The USA's proposal stated further that the primary threat to the population of Banggai cardinalfish was over-harvesting for the aquarium trade, coupled with habitat degradation and destruction, based on Vagelli's field studies. Being a fish associated with shallow waters and its relationship with sedentary benthic invertebrates, the Banggai cardinalfish is very susceptible to unsustainable harvest due to its restricted geographic distribution and in aggressive movement which make them easy to capture (Lunn \& Morreau, 2004; Ndobe et al., 2013). Furthermore, the level of harvest pressure had grown noticeably due to the increasing demand for this fish for export. For the fishermen in Banggai Islands, other livelihood options was limited, and thus harvest of the Banggai cardinalfish offer a good opportunities.

In response to the USA proposal, the FAO Expert Advisory Panel - as the expert advisory panel to the CITES Convention suggested that there was no evidence of a population decline in the Banggai cardinalfish's natural habitat. The FAO Expert Advisory Panel concluded that the species did not meet the biological criteria for an Appendix II listing, due to insufficient evidence of a decline in population numbers or number of sub-populations. In addition, the harvest pressure at the time of the surveys perhaps was confined to locations close to fishing villages, hence could create an underestimation of population size (FAO, 
2007). The Panel also noted that in 2004 the local Government of the District of Banggai had established two marine areas (Kokungan Bay in Banggai Island; and Latinbung in Bangkulu Island) as conservation areas for the Banggai cardinalfish.

With that in mind, the Panel suggested that the Government of Indonesia had been taking necessary steps to improve management and implement conservation of the Banggai cardinalfish. Therefore, listing the species into CITES Appendix II would hinder national management rather than promote it. The Panel also stated that strengthening local and national management efforts was highly recommended to be pursued (CITES, 2007). Following opposition from several Parties, including Indonesia as the only range state, USA withdrew the proposal to list Banggai cardinalfish on CITES Appendix II (Earth Negotiation Bulletin, 2007), in other words, Banggai cardinalfish was decided not to be included in the CITES Appendix II.

\subsubsection{Follow-Up Actions Post CITES COP 14}

In the effort to promote sustainable harvest and trade, as well as to protect the population of the Banggai cardinalfish, Indonesia's Ministry of Marine Affairs and Fisheries (MoMAF) in collaboration with the local government and relevant stakeholders issued a document entitled "Action Plan of Sustainable Harvest and Management of Banggai Cardinalfish 2007-2012”. The Action Plan covered management issues, harvest levels and sustainable trade of the Banggai Cardinalfish. Parallel to the Action Plan, the Head of the Regency of Banggai Archipelago declared Decree Bupati Bangkep No. 540/2007 on a Local Marine Protected Area (MPA) which covers 10 islands, including Banggai Island and Tongong Lantang Island (Ndobe et al., 2013).

As for breeding operation, the captive breeding of Banggai cardinalfish turned up to be highly feasible, both biotechnologically and financially. Using simple facilities, breeders might raise marketable-sized fish within 100-130 days with survival rates of $66 \%$ to $95 \%$ (Hopkins et al., 2005). Therefore, the MoMAF started promoting commercial breeding of Banggai cardinalfish in cooperation with the local government. The breeding operation was started in the MoMAF research institution, Balai Besar Benih Ambon (Fish Hatchery Technical Unit in Ambon, Maluku), hoping that the breeding operation would contagiously spread out to the fishermen in Banggai Islands who depend on this fish for their livelihood.

Following the breeding success of this species in Balai Besar Benih Ambon, three other breeders have successfully started breeding operation (Table 1). Recently the government also promoted captive breeding of Banggai cardinalfish to the communities in other parts of Indonesia, including in Jakarta, Riau Archipelago (Sumatra), Northwest Bali, Lombok, Kendari, and Lampung (southern Sumatra). In addition to

Table 1. List of active breeders of Banggai cardinalfish (Pterapogon kauderni) in Indonesia (Direktorat KKHL, 2019; Gayatri Reksodihardjo-Lilley, the founder of Yayasan Alam pers. comm. on 8 August 2019).

\begin{tabular}{clll}
\hline No. & \multicolumn{1}{c}{ Breeder Name } & \multicolumn{1}{c}{ Location } & \multicolumn{1}{c}{ Owner } \\
\hline 1 & Balai Besar Benih Ambon & Ambon, Maluku & Government \\
2 & Bali Aquarich & Buleleng, Bali & Private company \\
3 & Yayasan Alam Indonesia Lestari & Buleleng, Bali & Civil society/NGO \\
4 & Kelompok Masyarakat BCF & Bone Baru, Banggai & Community \\
& Lestari & Laut & \\
\hline
\end{tabular}


captive breeding, population introduction was also carried out in those areas (Ndobe et al., 2019; Reksodihardjo, 2015).

Breeding of the Banggai cardinalfish has the potential to flood the market and to decrease the pressure on wild populations. It was reported that since 2012 captive breeding was able to supply half of the international market (FAO, 2016). However, fishermen preferred to capture the Banggai cardinalfish from the wild, considering that captive breeding requires a financial investment. Also, fish traders still prefer to buy wild-caught specimens, as they were much cheaper, although captive-bred specimens could be promoted as disease-free fish and a sustainable product. Hence, wild capture was suspected still dominant (Vagelli, 2011).

Table 2. Annual export of wild-caught Banggai cardinalfish (Pterapogon kauderni) from Indonesia, 20072016 (Dit KKHL, 2019).

\begin{tabular}{ccc}
\hline No & $\begin{array}{c}\text { Year of } \\
\text { Export }\end{array}$ & $\begin{array}{c}\text { Quantity of Export } \\
\text { (Specimens) }\end{array}$ \\
\hline 1 & 2007 & 200,864 \\
2 & 2008 & 347,362 \\
3 & 2009 & 368,616 \\
4 & 2010 & 329,575 \\
5 & 2011 & 239,455 \\
6 & 2012 & 153,242 \\
7 & 2013 & 179,225 \\
8 & 2014 & 149,240 \\
9 & 2015 & 167,990 \\
10 & 2016 & 45,850 \\
11 & 2017 & 61,650 \\
12 & 2018 & 299,549 \\
13 & 2019 & $67,784 *$ \\
\hline
\end{tabular}

*up to August

As the Banggai cardinalfish has been raised to international attention due to USA's proposal, since 2007 the MoMAF carefully recorded the export of wild-caught of this species. From 2007 to 2016 the average annual export of the species was 217,498 specimens (Table 2), much lower than export data in 2001-2004 listed in the USA's proposal (i.e. 700,000 - 900,000 specimens/year).

\subsubsection{The Second Attempt for the Inclusion of the Banggai Cardinalfish (Pterapogon kauderni) into CITES Appendix II}

In 2015, upon a consultation with the Government of Indonesia, the European Union (EU) and its Member States indicated that they would re-launch the proposal for listing the Banggai cardinalfish into CITES Appendix II. In April 2016, Indonesia expressed opposition to the proposal but welcomed the support to strengthen the current management of the Banggai cardinalfish. Despite Indonesia's disagreed position, the proposal for the inclusion of the Banggai cardinalfish into CITES Appendix II was announced at the CITES COP 17 in Johannesburg (South Africa) in September 2016 (CITES, 2017).

The proposal referred mainly to the study by the same expert, (Vagelli, 2008; 2011) in islands in the Regency of Banggai Islands, as well as other studies conducted by various researchers. The proposal indicated that the wild harvest for aquarium trade in 2007 reached an estimate of 900,000 specimens, much higher than the data of Indonesian MoMAF (Table 2). There was a question whether MoMAF only recorded the legal export and disregarded the illegal export. This discrepancy became a big argument among Parties in the Convention. The proposal further refers to previous studies (Ndobe et al., 2013), which reported the extirpation of sub-populations in some areas in Banggai Islands including subpopulation around Islands of Limbo, Masoni, Bakakan and Peleng Liang (Hopkins et al., 2005).

The EU proposal noted the conservation measures that has been taken by Indonesia, including captive breeding of the species, which already existed in several 
areas in Indonesia, as well as the success of species introduction outside their original habitat in various areas: Palu Bay in Central Sulawesi (Moore \& Ndobe, 2007), Lembeh Strait (Makatipu et al., 2013), Tumbak in North Sulawesi (FAO, 2016), Kendari in Southeast Sulawesi (Moore et al., 2011) and North Bali (Lilley, 2008). The EU also recognized Indonesia's initiative in establishing a Local MPA in the Banggai Archipelago to protect the Banggai cardinalfish. However, there was a concern on genetic diversity, because the Local MPA was located beyond the major marine biodiversity of the area (Ndobe et al., 2012). For that reason, the EU proposal concluded that the Banggai cardinalfish was qualified for inclusion in Appendix II, by satisfying both Criteria A and B of Annex 2a of Resolution Conf. 9.24. The proposal also underlined that the listing the Banggai cardinalfish into CITES Appendix II could ensure the sustainable harvest by the local people over a long-term period.

The FAO Expert Advisory Panel noted that the species has a high productivity and exhibits an excellent ability to recover from human and environmental pressure. The recent introduction into new locations also would ensure a good ability to stabilize the harvest pressure. However, the Panel supported the EU proposal to include the Banggai Cardinalfish into CITES Appendix II.

The Panel further states that listing the Banggai cardinalfish into CITES Appendix II would help Indonesia in recording global trade, ensure traceability of the species which could prevent illicit trade activities, and ensure the effectiveness in dealing with international trade issues. The listing would, however, require further administrative work. The Panel also underlined the role and need to strengthen the existing captive breeding of the species (Vagelli, 2004).

Indonesia considered that the current implementation of existing management measures would be able to ensure the survival and conservation of the Banggai cardinalfish. Indonesia also voiced some concerns as follows: (a) listing the species into CITES Appendix II might disrupt the current management efforts as it requires more investment in both capacity and resources, in particular at the local level, (b) the listing might be counter-productive, because the government had to focus on and be in compliance with international regulations, CITES rules, and bureaucracy, rather than concentrate on conserving the species, (c) the listing of Banggai cardinalfish into Appendix II might generate other challenges, such as illegal trade (Direktorat Keanekaragaman Hayati Laut, 2016).

The Government of Indonesia would prefer to impose national and local regulations regarding harvest season of Banggai cardinalfish and to restrict harvest areas across Banggai cardinalfish habitat, including introduction into new areas. With that, it would allow stock recovery and at the same time promote educating local fishermen in doing sustainable harvest while introducing community harvest monitoring and improving chain of custody mechanisms (Vagelli, 2011).

\subsubsection{Decision of the CITES Convention}

The battle whether the Banggai cardinalfish be included in CITES Appendix II based on EU proposal was decided in CITES COP 17. The CITES COP 17 adopted four decisions as follows: (a) request Indonesia to implement conservation and management measures to ensure the sustainability of international trade in Banggai cardinalfish, and report progress on these measures to the Animals Committee at its 30th meeting, (b) request the Secretariat, subject to external funding, to commission a study to assess the impact of international trade on the conservation status of the Banggai cardinalfish and to advise on sustainable conservation and management as 
appropriate, (c) instruct the Animals Committee to, at its 30th meeting, review the progress report submitted by Indonesia as referred to under Decision 17.259, as well as the results of the study as referred to under Decision 17.260, and make its recommendations to the COP 18 , (d) donor Parties and other relevant organizations, including the FAO, are invited and encouraged to provide support to Indonesia and to the Secretariat.

The COP Decision has endorsed Indonesia to maintain the species beyond CITES Appendices, but was requested to follow the recommendation under Decision 17.259. Following the CITES decision, the EU withdrew its proposal to the Convention. This means that for the second time, the Banggai Cardinalfish was failed to be included in the CITES Appendix II, and thus export of this species will not be regulated by the international mechanism.

Following the CITES COP Decision, upon the co-financial supports of the National Oceanic Atmospheric Administration (NOAA) and the EU, the CITES Secretariat has commissioned the IUCN Species Survival Commission (SSC) to assess the impact of international trade on the conservation status of Banggai cardinalfish (CITES, 2019). The Report by SSC was submitted to the 30th Meeting of the Animals Committee in Genève, Switzerland, 16-21 July 2018 (Ndobe et al., 2018). The SSC Report concluded that Indonesia has already initiated a number of relevant activities related to conservation and management of the species. Harvest and trade management had been well established. The Report also underlined the importance of captive breeding, human capacity, restocking, conservation governance and special incentives from the international market into local communities who work with the species (Ndobe et al., 2019).

The CITES Animals Committee at its 30th meeting welcomed the Report and congratulated Indonesia for making a substantial progress in activities and management measures to conserve the Banggai cardinalfish. The Committee, however, further recommends Indonesia to continue and share the studies and results beyond 2018, including plans a new MPA under provincial government and to rezoning the existing Local MPA to cover the major habitat for Banggai cardinalfish, introduction and restocking protocol, and safeguard mechanisms for populations beyond the origin habitat as well as to avoid further decline and restore the species population (CITES, 2018). Furthermore, the CITES Secretariat directed Indonesia to continue its management measure to ensure the sustainability of the trade of the species and recommended to report the progress to the Animal Committee at its 31st meeting (CITES, 2019).

\subsubsection{The Subsequent Policy by Indonesia, USA and EU Government}

In the effort to strengthen conservation and management of Banggai cardinalfish, in April 2019 the MoMAF issued a Ministerial Decree No. 49/KepMenKKP/2019 pertaining the Limited Protection of Banggai cardinalfish. The Decree regulates seasonal harvest whereby a closed season (harvest not allowed) is imposed during Banggai cardinalfsh breeding seasons, namely in February-March and October-November. The Decree was also attached a map where harvest during the period is prohibited. The area of the Decree includes the sea under the province of Central Sulawesi, District of Banggai, Banggai Kepulauan, and Banggai Laut (KEPMEN-KKP, 2019).

As for the international trade, subsequent to the decision on the CITES at COP 17, the US Government on 20 January 2016 has listed the Banggai Cardinalfish into the Endangered Species Act, meaning that it is treated as threatened species and, therefore, it is prohibited for commercial 
importation of the species to the USA (NOAA 2016). Meanwhile, the EU has listed the species under the strict domestic measure and suspension might be applied regulation as stipulated in Commission Implementing Regulation (EU) No. 792/2012 adopted on 23 August 2012. However, upon the Commission Implementing Regulation (EU) 2019/1587 issued on 24 September 2019, the species is not listed under Annex A EC Regulation No 338/97 whose introduction into the Union is prohibited, which means that trading the species with the EU Member States might be possible with certain criteria (European Commission on Environment, 2020).

\subsection{Discussion}

Although a certain fish (or other species) has an endemic distribution in a specific country or region, international community will keep an eye on the species when the volume in the international trade considered to be in an alarming situation. Banggai cardinalfish is an example of this case.

The issues of population depletion of Banggai cardinalfish has been hanging since 2007 when the IUCN listed the species into endangered species, followed by the proposal of listing the species into CITES Appendix II. At the time FAO has made clear objection to the CITES motion and suggested that scientific data was not adequate to support the listing and hence further studies were required. Indonesia then managed to escape the listing. Learning from this, clearly scientific methods to estimate the fish population and its trend after being harvested is very crucial in decision making process.

Marine conservationist and scientists were fully aware that unsustainable harvest has contributed to the population decline of the species in their habitat. The species also associated with coral reef, quite frequent in degraded reef, anemones, seagrass, jellyfish, and sea urchins. Unfortunately, these associated species also have been the target of commercial harvest, which contributed the population pressure of the species which might end up with local extinction.

In the long run, the population introduction of the Banggai cardinalfish beyond its original geographic ranges might create ecological issues, including the question whether the species could disrupt the existing ecological balance or become invasive in its new habitat range. Bringing the species outside its original distribution would also create potential market competition with local community in Banggai, which in turned diminish local livelihood derived from the species. These possible ecological and economical impact surely worth to be studied further.

Captive breeding of Banggai cardinalfish still has unresolved challenges, such as the absence of marking of the specimens. Without marking of captive-bred specimens, the specimens are impossible to differentiate from wild capture. Buyers who want to buy captive-bred specimens for the sustainability reason might mixed-up with wild-caught specimen.

Following the success of rejecting the first and the second attempt for the inclusion of Banggai cardinalfish into CITES Appendix II, the MoMAF has issued limited protection of the species and imposed closed session for harvesting the species. Unfortunately, the Decree does not regulate or provide guidance concerning harvest mechanisms and harvest levels during the open season. On the absence of clear guidance and strong safeguard controls, the Decree therefore has a loophole, which may lead to the interpretation that harvests outside that period are allowed at maximum levels, in particular where other safeguards are not in place.

Regarding the export issue, although the market for Banggai cardinalfish to USA was closed and to EU was limited, export to other countries are still wide open. International community, however, will keep 
monitoring the number of Banggai cardinalfish that enter the international market. In the past, there were two attempts to include this species into CITES Appendix II and both were failed. However, there was no guarantee that there will not be a third attempt by other CITES Party. The Government of Indonesia still need to show to the international market that Indonesia manages the Banggai cardinalfish in proper ways, to ensure the sustainability of this species and its trade.

\section{CONCLUSION}

The Banggai cardinalfish clearly is an Indonesian species, distributed only in Banggai Island and its surrounding. However, in the global conservation effort, international community has been involved as well, including IUCN, CITES and other parties of the CITES. The first and the second attempts to include this species into Appendix II was originated from other countries, triggered Indonesian Government to take necessary policy, research and actions to show that Indonesia tried to manage its resources in proper ways.

International negotiation within CITES and other Convention is not an easy task. Various institutions and researchers, both from local, national and international levels, have to be working together to provide necessary information for decision makers. Although the Banggai cardinalfish was escaped from CITES Appendix II, many actions still need to be done, basically aiming at making sure that the species and its trade would be sustainable.

\section{ACKNOWLEDGMENTS}

We would like to thank Mr. Andi Rusandi, Director of Conservation of Marine Biodiversity MoMAF, Ms. Gayatri R-Lilley (Director and Founder of Yayasan Alam Indonesia Lestari, Abigail Moore (Yayasan Palu Hijau), as well as Mr. Kim Worm
Sorensen for kindly sharing their expert knowledge of Banggai cardinalfish and for his direct and indirect inputs to this paper. We also thank an anonymous reviewer who provide guidance for the clarity and improvement of this paper.

\section{REFERENCES}

Convention on International Trade in Endangered Species (CITES). 2007. Consideration of proposals for amendment of Appendices I and II. Fourteenth meeting of the Conference, 2007, Hague, Netherlands, 3-15 June 2007. CoP14 Prop. No.19.

Convention on International Trade in Endangered Species (CITES). 2017. Consideration of proposals for amendment of Appendices I and II. Seventeenth meeting of the Conference, 2018, Johannesburg, South Africa, 24 September - 5 October 2016.

Convention on International Trade in Endangered Species (CITES). 2018. Conservation and management measures to ensure the sustainability of international trade in Pterapogon kauderni. Decision No. 17.259 (ref. CoP 17).

Convention on International Trade in Endangered Species (CITES). 2019. Banggai cardinalfish (Pterapogon kaudeni). Eighteenth meeting of the Conference, 2019, Colombo, Sri Lanka, 23 May-3 June 2019.

Direktorat Konservasi dan Keanekaragaman Hayati Laut (Dit KKHL). 2016. Rencana Aksi Nasional (RAN) ikan capungan Banggai Banggai periode 1:2017-2021. Kementerian Kelautan dan Perikanan. Indonesia. Jakarta. ISBN 978-602-7913-55-4. 57 p.

Direktorat Konservasi dan Keanekaragaman Hayati Laut (Dit KKHL). 2019. Database Direktorat Konservasi dan Keanekaragaman Hayati Laut, 
Kementerian Kelautan dan Perikanan Unpublished report.

Earth Negotiation Bulletin. 2007. Summary of the fourteenth Conference of the Parties to the Convention on International Trade in Endangered Species of Wild Fauna and Flora, 2: 61.

Erdmann, M.V. \& A. Vagelli. 2001. Banggai cardinalfish invade Lembeh Strait. Coral Reefs, 20(3): 252-253. http://doi.org/10.1007/s003380100174

Food and Agriculture Organization (FAO). 2007. FAO Fisheries Report No. 833 Second FAO Ad-Hoc Expert Advisory Panel for the assessment of proposals to amend Appendices I and II of CITES concerning commerciallyexploited aquatic species. Food and Agriculture Organization of the United Nations, Rome. 141 p.

Food and Agriculture Organization (FAO). 2016. Report of the $5^{\text {th }}$ FAO Expert Advisory Panel for The Assessment of Proposals to Amend Appendices I and II of CITES concerning commerciallyexploited aquatic species. Rome. 121 p. http://www.fao.org/3/a-i5932e.pdf

Hopkins, S., H. Ako, \& C.S. Tamaru. 2005 Manual for the production of the Banggai cardinalfish, Pterapogon kauderni, in Hawaii. In: Hopkins et al. (eds.). College of Tropical Agriculture and Human Resources, Department of Molecular Biosciences and Biosystems Engineering, University of Hawaii Sea Grant College Program, Hawai. 32 p. http://www.raingarden.us/banggaiman ual.pdf

Indrawan, M. \& Suseno. 2008. The complication of CITES inclusion of endemic species in Indonesia: Lesson learned from an in country deliberation on protecting the Banggai cardinalfish, Pteropogon kauderni. SPC Live Reef Fish Information Bulletin, 18: 13-16.

International Union for Conservation of Nature (IUCN). 2007. Pterapogon kauderni. The IUCN Red List of Threatened species.

https://www.iucnredlist.org/species/63 572/12692964

Lilley, R. 2008. Banggai cardinalfish: An overview of conservation challenges. SPC Live Reef Fish Information Bulletin, 18: 3-12.

Lunn, K.F. \& M.A. Moreau. 2004. Unmonitored trade in marine ornamental fishes: The case of Indonesia's Banggai cardinalfish (Pterapogon kauderni). Coral Reefs, 23: 344-351.

http://doi.org/10.1007/s00338-0040393-y

Makatipu, P.C., T. Peristiwady, N. Manik, I. Pulukadang, P.M. Risqi, M. Djabar, \& N. Mahmoud. 2013. Standing stock dan pemeliharaan induk ikan capungan Banggaian Banggai cardinalfish (Pterapogon kauderni, Koumans, 1933) di Selat Lembeh, Bitung, Sulawesi Utara. Laporan Kegiatan Unit Pelaksana Teknis Loka Konservasi Biota Laut Pusat Penelitian Oseanografi, Lembaga Ilmu Pengetahuan Indonesia, Bitung.

Ministry of Marine Affairs and Fisheries (KKP). 2018. Keputusan Menteri Kelautan dan Perikanan Republik Indonesia nomor 49/Kepmen-KP/2018 tentang Penetapan status pelindungan terbatas ikan capungan Banggai (Pterapogon kauderni). KKP. Jakarta.

Moore, A. \& S. Ndobe. 2007. Discovery of an introduced Banggai cardinalfish population in Palu Bay, Central Sulawesi, Indonesia. Coral Reefs, 26(3): 569-569. http://doi.org/10.1007/s00338-0070227-9

Moore, A., S. Ndobe, \& M. Zamrud. 2011. Monitoring the Banggai cardinalfish, an endangered restricted range endemic species. J. of Indonesia Coral Reefs, 1(2): 99-113. http://doi.org/10.31230/osf.io/scvfm 
National Oceanic and Atmospheric Administration (NOAA). 2016. Endangered and threatened wildlife and plants: Final listing determinations on proposal to list the Banggai cardinalfish and Harrisson's dogfish under the Endangered Species Act. National Achieve Federal Register. https://www.federalregister.gov/docum ents/2016/01/20/201600943/endangered-and-threatenedwildlife-and-plants-final-listing-

Ndobe, S., D. Setyohadi, E.Y. Herawati, Soemarno, \& A. Moore. 2012. An ecological and social approach to Banggai cardinalfish conservation management. In: Yellowless et al. $(e d s)$. Proceedings of the $12^{\text {th }}$ International Coral Reef Symposium, 2012, Cairns, Australia, 9-13 July 2012.

Ndobe, S., A. Moore, A.I.M. Salanggon, Maslihudin, D. Setyohadi, E.Y. Herawati, \& Soemarno. 2013. Banggai cardinalfish (Pterapogon kauderni) management: An ecosystem-based approach. Marine Fisheries, 4(2): 115126.

https://doi.org/10.29244/jmf.4.2.115126

Ndobe, S., A. Moore, I. Yasir, \& J. Jompa. 2019. Banggai cardinalfish conservation: priorities, opportunities, and risks. IOP Conf. Series: Earth and Environmental Science, 253: 012033. http://doi.org/10.1088/17551315/253/1/012033

Ndobe, S., I. Yasir, A.M. Moore, M.V. Biondo, \& S.J. Foster. 2018. A study to assess the impact of international trade on the conservation status of Pterapogon kauderni (Banggai cardinalfish). In: Convention on International Trade in Endangered Species of Wild Fauna and Florra (CITES) 2018, Thirtieth meeting of the Animal Committee, Geneva,
Switzerland, 16-21 July 2018. IUCN Species Survival Commission. 64 p.

Reksodihardjo, G.L. 2015. Concerns about the conservation of the Banggai cardinalfish. OFI Journal, 78: 8-9.

Soehartono, T.R. \& A. Mardiastuti. 2002. CITES implementation in Indonesia. Nagao Natural Environment Foundation. Jakarta. 16-20 pp.

Talbot, R., M. Pedersen, \& J.M. Lawrence 2012. Banggai rescue: Adventure in bringing Pterapogon kauderni back from the brink. A manual for aquarists, divers, and breeders. Reef to Rainforest. 158 p.

https://reefs.com/2012/03/12/rescueproject-comes-to-the-aid-of-theendangered-banggai-cardinalfish/.

Vagelli, A.A. \& M.V. Erdmann. 2002. First comprehensive ecological survey of the Banggai cardinalfish, Pterapogon kauderni. Env. Biol. Fish, 63: 1-8. http://doi.org/10.1023/A:10138840202 58

Vagelli, A.A. 2004. Otogenetic shift in habitat preference by Pterapogon kauderni, a shallow water coral reef Apogonid, with notes on new releases behaviour. Copeia, 2: 364-369. http://doi.org/10.1643/CE-03-059R2

Vagelli, A.A. 2005. Reproductive biology, geographic distribution and ecology of the Banggai cardinalfish Pterapogon kauderni Koumans, 1933 (Perciformes, Apogonidae), with considerations on the conservation status of this species on its natural habitat. PhD. dissertation. University of Buenos Aires. $276 \mathrm{p}$.

Vagelli, A.A. 2011. The Banggai cardinalfish: natural history, conservation, and culture of Pterapogon kauderni. WileyBlackwell. United Kingdom. 224 p.

European Commission on Environment. 2020. The European Union and trade in wild fauna and flora. 
Banggai Cardinalfish (Pterapogon Kauderni) and the Attempt ...

https://ec.europa.eu/environment/cites/ legislation_en.htm.
Received : 19 June 2020

Reviewed : 8 July 2020

Accepted : 30 August 2020 